The Geneva Papers on Risk and Insurance, 14 (No. 53, October 1989), 331-346

\title{
Expanding Tort Liability in English Law and Compulsory Insurance for Professional Risks
}

\author{
by David Oughton*
}

\begin{abstract}
A proposal to introduce a requirement of compulsory third party insurance for professional risks should be considered in the light of its potential for triggering off an expansion in the tortious liability of the professional provider of a service. It is suggested that the presence of insurance cover can herald a judicial willingness to expand the boundaries of the tort of negligence. Such an expansion may create uncertainties amongst insurers as to where liability will stop. This uncertainty, in turn, is likely to lead to a substantial increase in insurance premiums, to the point where the cost of insurance is prohibitive, or to other defensive tactics on the part of insurers. One consequence of the prohibitive cost of insurance may be to force the provider of high-risk services to abandon their provision, culminating in a net loss to the community.
\end{abstract}

\section{The expansion of the tort of negligence in respect of professional risks}

It is undoubtedly the case that the tortious liability of professional service providers has been extended in recent years. While a solicitor, at one stage, was liable only to the extent provided by his retainer with his client, ${ }^{1}$ it is now the case that his liability sounds in contract and in tort. ${ }^{2}$ The view that a professional person may be liable in tort, provided the ingredients of the cause of action exist, is now thought to apply to builders, ${ }^{3}$ surveyors, architects, accountants and other professional persons. ${ }^{4}$ The only professional who appears not to be subject to this expansion in liability is the advocate, ${ }^{5}$ who is considered not to have

* LL.B. M. Phil. Senior lecturer in Law, Liverpool Polytechnic.

1 Groom v Crocker [1939] 1 KB 194; Clark v Kirby-Smith [1964] Ch 506. See also Kaye, The Liability of Solicitors in Tort (1964) 100 LQR 680.

${ }^{2}$ Midland Bank v Hett, Stubs, Kemp \& Co. [1979] Ch 384. Approved in Forster v Outred \& Co. [1982] 1 WLR 86. Cf Tai Hing Cotton Mill Ltd. v Liu Chong Hing Bank Ltd. [1986] AC 80 at 107 per Lord Scarman.

${ }^{3}$ Batty v Metropolitan Realisations [1978] QB 554. Cf D \& F Estates Ltd. v Church Commissioners for England [1988] 2 All ER 992.

${ }_{4}^{4}$ Yianni v Evans [1982] QB 438 (surveyor): Acrecrest $v$ W.S. Hattrell \& Partners [1983] 1 All ER 17 (architect); J. E. B. Fasteners Ltd. v Marks, Bloom \& Co. [1981] 3 All ER 289 affd. [1983] 1 All ER 583 (accountant).

${ }^{5}$ Similar principles apply to arbitrators (Arenson v Casson, Beckman, Rutley \& Co. [1977] AC 405) and to judges (Sciros v Moore [1975] QB 118). 
contracted with his client, ${ }^{6}$ and whose tortious liability is severely restricted for reasons of public policy. ${ }^{7}$ Whether or not this immunity should continue to exist is a separate matter, although it may be argued that the lifting of the immunity might serve to improve the quality of legal services. ${ }^{8}$

In addition to professional advisers, it has long been the case that the liability of a medical practitioner may be based on a breach of his tortious duty of care as well as under a contract he may have made with a private patient.

In recent years, the extent of the professional person's liability has been further extended. While it used to be the case that no action could be maintained by a third party against a solicitor, ${ }^{9}$ this is no longer the case where it is foreseeable that the third party might be adversely affected by the solicitor's failure to take reasonable care. ${ }^{10}$ Similarly, the liability of an accountant ${ }^{11}$ and a surveyor ${ }^{12}$ now extends to third parties in appropriate circumstances. This is particularly the case where the professional adviser is engaged to do work specifically for the benefit of the third party, ${ }^{13}$ or where the third party has clearly relied on the adviser to take care. ${ }^{14}$

The liability of the medical practitioner has also expanded, although not to the same extent as in other jurisdictions, such as the U.S.A. While the duty of care used to be owed to the patient alone, it is now the case that a limited duty is owed to a child in utero. 15 However, no action lies for "wrongful life". ${ }^{16}$ While no action for wrongful life may be brought, it may be possible for the parents of an unwanted child to bring an action for "wrongful birth", for example, where a child is born due to the failure of an operation to sterilise one of the parents. In such circumstances, damages may be awarded for disturbance to family finances, ${ }^{17}$ and for pre-natal and post-natal medical expenses, pain and suffering, loss of consortium and the reasonable cost of rearing the unplanned child. ${ }^{18}$

${ }^{6}$ Kennedy v Broun [1863] 13 CBNS 677; Swinfen v Lord Chelmsford [1860] 5 H \& N 890. See also Supply of Services (Implied Terms) Order 1982 (SI 1982/1771) Art. 2(1).

${ }^{7}$ Rondel $v$ Worsley [1969] 1 AC 191. While an advocate is not liable for his conduct of litigation or advice given in this regard, he may be liable in the tort of negligence for advice which is not concerned with litigation or advice which prevents the client's case form being heard at all. (Saif Ali v Sydney Mitchell \& Co. [1980] AC 198). To this extent, there would appear to be an expansion of liability.

${ }^{8}$ Veljanovski \& Whelan, Professional Negligence and the Quality of Legal Services - An Economic Perspective [1983] 46 MLR 700.

${ }^{9}$ Robertson v Fleming [1861] 4 Macq 167.

${ }_{10}$ Ross v Caunters [1980] Ch 297; Clarke v Bruce Lance \& Co. [1988] 1 All ER 364 at 367 per Balcombe LJ; Al-Kandari v JR Brown \& Co [1988] 1 Al ER 833.

$11 \mathrm{~J}$ E B Fasteners $v$ Marks, Bloom \& Co note 4 above.

12 Yianni $v$ Evans note 4 above.

${ }^{13}$ Ross $v$ Caunters note 10 above. A duty of care may also be owed by a solicitor to a person intended to be benefitted by a court order made against his client; Al-Kandari $v$ Brown note 10 above.

14 Wilson v Bloomfield [1979] 123 Sol Jo 860.

15 Congenital Disabilities (Civil Liability) Act 1976 s 1(1) and s 1(2).

${ }^{16}$ Congenital Disabilities (Civil Liability) Act 1976 s 1(2) (b). See also McKay v Essex Area Health Authority [1984] 2 WLR 890.

17 Udale v Bloomsbury Area Health Authority [1983] 2 All ER 522.

${ }^{18}$ Emeh v Kensington, Chelsea \& Westminster Area Health Authority [1984] 3 All ER 1044. See also Thake v Maurice [1986] 1 All ER 497. 
The notion of breach of duty has been used, in the past, to limit the extent of a medical practitioner's liability. For example, it has been erroneously stated that a mere error of judgment on the part of a doctor does not amount to negligence. ${ }^{19}$ However, it has subsequently been held that an error of judgment can constitute negligence if it is glaringly below proper standards. ${ }^{20}$ The appropriate test to apply is that of the ordinary skilled man exercising and professing to have the special skill under consideration. ${ }^{21}$ It follows from this that inexperience is not a defence, ${ }^{22}$ and that a junior doctor may be guilty of negligence in circumstances where he has been required to work very long hours due to apparent under-funding of the National Health Service. While the present test of liability is that of the reasonable doctor, it should be noted that the test is not static, and that there is potential for the expansion of the liability of a medical practitioner, since advances resulting from clinical and technological research must be taken into account. To this extent, it may be regarded as a reasonably flexible test of liability. One step which has not been taken in English law is to adopt the transatlantic doctrine of "informed consent", ${ }^{23}$ which would allow the court to determine the liability of the doctor by reference to the standard of care considered necessary by a "prudent patient" so as to make an informed consent to a medical procedure. ${ }^{24}$

It can be seen from what has been said already that there has been a steady expansion in the range of potential plaintiffs in an action for professional negligence. Furthermore, developments to date indicate that there may also be a potential for further expansion. In addition to this, the tort of negligence has also expanded in terms of the types of loss recoverable. It is now the case that a person may recover damages in respect of physical harm, emotional harm, property damage and economic loss. However, the recovery of the latter would appear to be under very close judicial scrutiny. These developments have not been avoided by the professional provider of a service.

The typical loss suffered in cases of medical malpractice is physical harm. However, in some instances, the plaintiff may suffer economic loss. For example, where an action is brought for wrongful birth, damages may be awarded for disruption of family finances and for the reasonable cost of rearing the child. Such losses may be properly regarded as a direct

${ }^{19}$ Whitehouse v Jordan [1980] 1 All ER 650 at 658 per Lord Denning MR (C.A.).

${ }^{20}$ Whitehouse v Jordan [1981] 1 All ER 267 at 280-281 per Lord Fraser; at 276 per Lord EdmundDavies, and at 284 per Lord Russel.

${ }^{21}$ Bolan v Friern Hospital Management Committee [1957] 2 All ER 118 at 121 per McNair J, approved in Whitehouse v Jordan [1981] 1 All ER 267 (HL) (negligence in treatment); Maynard v Vest Midlands Regional Health Authority [1985] 1 All ER 635 (HL) (negligence in diagnosis); Sidaway v Bethlem Royal Hospital (Governors) [1985] 1 All ER 643 (HL) (negligence in therapeutic advice); Gold v Haringay Area Health Authority [1987] 2 All ER 888 (negligence in non-therapeutic advice).

22 Wilsher $v$ Essex Area Health Authority [1986] 3 All ER 801 (C.A.) reversed on other grounds in [1988] 1 All ER 871 (HL).

${ }^{23}$ The most far-reaching statement of this doctrine is to be found in Canterbury $v$ Spence $464 \mathrm{~F} 2 \mathrm{~d}$ (D C Cir 1972).

${ }^{24}$ This doctrine did commend itself to Lord Scarman in Sidaway v Bethlem Royal Hospital (Governors) [1985] 1 All ER 643 at 653. In particular, it may be objected that the present reasonable doctor test leaves it in the hands of the medical profession to decide what is the appropriate standard of care. This would appear to disregard the principle of self-determination which dictates that the patient should be as fully informed as possible so that he can make an informed consent to medical treatment. 
consequence of a violation of personal integrity, which serves to distinguish these cases from other varieties of economic loss.

Where an accountant or a solicitor has failed to take reasonable care, the loss suffered by the client or a third party will usually be financial in nature. Recovery of these losses by the client can be justified on the basis that he is in a contractual relationship with his adviser.

Sometimes, the result of a professional adviser's negligence is a violation of personal integrity. For example, the failure of a solicitor to obtain a non-molestation order for the benefit of his client may result in his client suffering distress ${ }^{25}$ or physical injury. Similarly, the failure of a solicitor to comply with the requirements of a court order made against his client is capable of inflicting physical harm or emotional distress upon the intended beneficiary of the order. ${ }^{26}$

The harm which may be suffered as a result of an architect's negligence is diverse. It may be that a person is injured, or that property is damaged or the loss may be purely financial in nature, for example, where the value of the building is diminished.

\section{The effect of insurance in encouraging an expansion of tortious liability}

It has been observed that there has been a steady expansion in the tortious liability of professional persons. An influencing factor in this expansion may be the presence of third party or liability insurance. At one stage, it used to be regarded as improper to inform the court that the defendant was insured, ${ }^{27}$ but such a view is now regarded as old-fashioned, ${ }^{28}$ and frequently, the court will openly admit to the presence of insurance. ${ }^{29}$ It has been observed in the context of maritime collisions that, "most collision cases are collisions between insurance companies". 30

While the existence of an insurance policy may be admitted, it does not necessarily follow that this is an influence on the question of tortious liability. It has been said that the presence of insurance is not a reason for imposing liability. ${ }^{31}$ However, it is also the case that the fact of insurance may "add a little tensile strength to the chain that binds a wrongdoer to his responsibilities". ${ }^{32}$ In other cases, a court may choose to bolster its decision that a duty of care is owed by reference to the existence of insurance. ${ }^{33}$ But does all of this indicate that the fact of insurance is relevant to liability? In some instances this is the case. For example, the availability of insurance is directly relevant where the plaintiff seeks to

\footnotetext{
${ }^{25}$ Heywood $v$ Wellers [1976] 1 All ER 300.

${ }^{26}$ Al-Kandari v J R Brown \& Co [1988] 1 All ER 833.

${ }^{27}$ Davie v New Merton Board Mills [1959] AC 604 at 627 per Viscount Simmonds.

${ }_{28}$ Morey $v$ Woodfield [1963] 3 All ER 533 (n).

${ }^{29}$ Post Office $v$ Norwich Union Fire Insurance Soc Ltd [1967] 2 QB 363 at 375 per Lord Denning MR. See also Lamb v Camden London Borough Council [1981) QB 625 at 628 per Lord Denning MR.

30 The Abidin Daver [1984] AC 398 at 420 per Lord Templeman.

31. Lister $v$ Romford Ice and Cold Storage [1957] AC 555 at 576 per Viscount Simmonds; White $v$ Blackmore [1972] 3 All ER 158 at 168 per Lord Denning MR.

${ }^{32}$ Executor Trustee and Agency Co Ltd $v$ Hearse [1961] SASR 51 at 54 per Chamberlain J.

33 S C M (UK) Ltd v Whittall \& Son Ltd [1971] 1 QB 337 at 344 per Lord Denning MR; Spartan Steel \& Alloys Ltd v Martin \& Co (Contractors) Ltd [1973] QB 27 at 38 per Lord Denning MR.
} 
make a solicitor vicariously liable for the fraudulent acts of his managing clerk. ${ }^{34}$ Furthermore, it may be argued that legal rules have been invisibly affected by the existence of insurance. ${ }^{35}$ For example, a learner driver has to observe the same standard of competence as a fully licensed driver, ${ }^{36}$ and a junior houseman must exercise the same degree of care as a senior colleague. ${ }^{37}$ The fact of insurance may have prompted the development of the manufacturer's duty of care and the transformation of the doctrine of res ipsa loquitur into a rule of near strict liability. Conversely, a finding of non-liability may be influenced by the fact that the plaintiff is, or ought to be, insured against the risk of loss under consideration. ${ }^{38}$

It could be argued that the level of damages will rise where it appears that the defendant is insured. This might be true in the United States, ${ }^{39}$ where the jury assesses damages, but the same is less likely to be true in English law where awards of damages are more stereotyped, since they are made by judges.

While it may be arguable that the decision in a particular case is not influenced by the fact of insurance, it cannot be denied that the practice of insurance has affected the development of common law rules. The fact that the imposition of liability upon an insured defendant will not be a crushing burden upon him has allowed courts to give substantial awards of damages. It might be argued that excessively high awards should be avoided, since this will result in an increase in insurance premiums, and could force smaller insurance companies out of business. ${ }^{40}$ There may be some substance in the first of these two points, since an increase in insurance premiums may cause financial disruption to business ${ }^{41}$ and, in some instances, could result in the withdrawal of a service from the market. The second point should not detain us, as it is unlikely that awards of damages will rise substantially in a short period, so that a properly managed business ought to be able to meet the rise in awards of damages over a period of time by raising the cost of premiums.

It would appear that the practice of insurance has probably influenced the development of common law rules, and may be responsible for an expansion of the tortious liability of professional persons. If a system of compulsory third party liability insurance were to be imposed upon all solicitors, ${ }^{42}$ accountants, architects and doctors, it might be argued that

\footnotetext{
${ }^{34}$ Lloyd v Grace-Smith \& Co Ltd [1912] AC 716. See also Ackworth v Kempe (1778) 99 ER 30.

${ }_{35}$ Fleming James, Accident Liability Reconsidered: The Impact of Liability Insurance (1948) 57 Yale LJ 549.

${ }^{36}$ Nettleship $v$ Weston [1971] 3 All ER 581.

${ }^{37}$ Wilsher $v$ Essex Area Health Authority [1986] 3 All ER 801 (C.A.) reversed on other grounds in [1988] 1 All ER 871 (HL). The House of Lords did not deal with the issue of standard of care.

${ }^{38}$ See Photo Production Ltd v Securicor Transport Ltd [1980] AC 827; Lamb v Camden London Borough Council [1981] 625; Leigh \& Sillivan Ltdv Aliakmon Shipping [1986] 2 WLR 906. at 171 .

${ }^{39}$ Kalvan, The Jury, the Law and the Personal Injury Damage Award (1958) 19 Ohio State LJ 158

40 Fletcher v Autocar Ltd [1968] 2 QB 322.

${ }^{41}$ Heaps $v$ Perrite Ltd [1937] 2 All ER 60 at 61.

42 Since 1976, a solicitor wishing to practice in England and Wales must purchase professional indemnity insurance under the Master Policy Indemnity Insurance Scheme arranged by the Law Society under powers conferred by the Solicitors Act 1974 s 37 . Surveyors are also required to be compulsorily insured. See C S W 20/27th December, 1984.
} 
a further expansion in the tortious liability of the professions might follow. Given that the central argument in favour of a compulsory insurance scheme is to ensure, as far as is possible, that those entitled to compensation receive it, it might be argued that, because all professions hold insurance against third party risks, there might be a temptation to extend professional liability still further.

The presence of an insured potential defendant would certainly appear to attract litigation. This is particularly so where the harm suffered consists of property damage, where the extent of loss may be great. For example, in Dennis $v$ Charnwood Borough Council, ${ }^{43}$ the plaintiff chose to proceed against an insured local authority when it was discovered that the builder responsible for the defects in their house was not insured. This instance is one example of the way in which the liability of local authorities went through a period of expansion in the 1970's and early 1980's. ${ }^{44}$ One response to the expansion in the liability of local authorities is for a local authority to deliberately fail to insure itself against risks of the kind under consideration. There is oral evidence to the effect that this tactic has been adopted by by Liverpool City Council, with the result that actions for negligent failure to inspect have been reduced to insignificant levels.

More recently, it has been recognised, presumably in the light of recent cutbacks in local authority funding, that such bodies should no longer be regarded as insurers for the building trade and its associated professionals. Since 1984, there has been a steady retraction in the liability of local authorities. ${ }^{45}$ Furthermore, there are now considerable doubts as to the extent of a builder's liability to a non-contracting party where that person has suffered econonic loss. ${ }^{46} \mathrm{By}$ analogy, this retraction should also apply to the liability of a local authority. If the insurance of professional risks were to be made compulsory, this might prompt additional litigation in respect of alleged professional negligence, which, in turn, could herald an expansion of liability.

\section{Insurance practice in the light of a possible expansion in tortious liability 47}

The economic effects of a legal rule are twofold. It may act as an incentive to loss prevention. If the provider of a service knows that he will be liable in damages if he fails to take reasonable care, he will take the necessary precautions to avoid that risk of loss. However, not every loss can be prevented economically. In some instances, the precautions necessary to avoid a particular risk of loss may be so great in terms of financial or social cost that loss

${ }^{43}$ [1983] QB 409.

${ }^{44}$ See Dutton v Bognor Regis United Building Co Ltd [1972] 1 QB 373; Anns v Merton London Borough Council [1978] AC 728; Acrecrest Ltd v W S Hattrell \& Partners [1983] QB 260; Dennis v Charnwood Borough Council [1983] QB 409.

${ }_{45}$ Peabody Donation Fund (Governors) v Sir Lindsay Parkinson \& Co Ltd [1985] AC 210; Investors in Industry Ltd v South Bedfordshire District Council [1986] 1 All ER 787; Currran v Northern Ireland Co-ownership Housing Association Ltd [1987] 2 All ER 13.

${ }^{46} D$ \& F Estates Ltd $v$ Church Commissioners for England [1988] 2 All ER 992.

${ }^{47}$ See Priest, Modern Tort Law and the Current Insurance Crisis (1987) 96 Yale LJ 1521-1590. 
prevention is not worthwhile. ${ }^{48}$ In such circumstances, where the loss cannot be avoided in a cost-effective manner, it becomes pertinent to enquire who is in the best position to insure against the loss. ${ }^{49}$ Once it is the case that further preventive measures become uneconomic, any expansion in tortious liability will lead to an increase in the volume of insurance taken out to cover the increased risk of liability. If tortious liability is extended, this will correspondingly increase the risks of an insurer, with the result that he will either have to increase premiums or adopt other tactics in order to keep premiums within acceptable limits.

\section{(a) Insurance Practice}

Insurance depends on a risk of loss having some degree of probability that it will or will not occur. This probability may be assessed in one of two ways. First, the underlying conditions which cause a particular event may be assessed. In order to assess the probability of a risk of loss emanating from a particular professional practice on a causal basis, the practice would have to be subjected to a series of trials in order to determine the number of times it causes the loss in question. This would not be practicable, so an alternative approach is to estimate the empirical probability that loss will occur on the basis of past experience..$^{50}$ If past experience is based on limited professional liability, it would seem to follow that an expanded liability will result in an increase in the probability of a particular loss. The greater the risk incurred by an insurer, the higher premiums will rise. What an insurer will aim to do is to collect as many low-risk clients as possible, and to segregate between low risks and high risks. In order to attract low-risk members of the insurance pool, the insurer must try to keep premiums as low as possible so as to make insurance an attractive proposition to those low-risk members. Once insurance becomes expensive, low-risk members will drop out and self-insure. If this happens, the insurer is left with a pool of higher risks which, in turn, will lead to an increase in premiums. This may cause yet more drop-outs at the low-risk end of the pool, and so the vicious circle continues.

In order to avoid this break up of the risk pool, the insurer will adopt various methods to reduce risks and keep premiums as low as possible. In first party insurance, this a lot easier than in the case of third party insurance. For example, the insurer can use information available to him from the insurance proposal to segregate low and high risks so that lower premiums can be offered to low-risk members and thereby keep them in the pool. This explains why the cost of motor vehicle insurance premiums is higher for a teenager than for a middle-aged person with a long history of no claims. The same is true of the distinction drawn between life assurance premiums paid by smokers and non-smokers.

A further device used by insurers to reduce the risk is to offer premium discounts to those members of the pool who will accept an excess provision, or deductible, in the policy,

\footnotetext{
${ }^{48}$ It was observed in Daborn v Bath Tramways Motor Co Ltd \& Smithey [1946] 2 All Er 333 at 336 that, "... if all the trains in this country were restricted to a speed of 5 miles an hour, there would be fewer accidents, but our national life would be intolerably slowed down" per Asquith LJ.

49 See above notes 35 to 38 .

${ }^{50}$ See Vaughan \& Elliott Fundamentals of Risk and Insurance (2nd edn, 1978) pp 19-20. Information obtained from past experience may be useful in avoiding future losses. For example, as a result of an analysis of the claims pattern under the Solicitors' Master Policy Indemnity Scheme, a booklet has been published advising on how to improve office administration, supervise staff etc. See Solicitors' Professional Negligence - The Source of Prevention of Claims (London Insurance Brokers Ltd, 1981).
} 
or who will accept reduced insurance cover at the top end. In this way, minor losses will be paid for by the insured himself due to the excess provision, and any loss above the limit of cover will also be paid for by the insured or another insurer who may have agreed to cover the additional liability. Thus, as excess provisions increase and cover is reduced, the insurer narrows the range of risks covered by the policy. In this way, the highest risks of loss fall outside the policy, and the insurer can keep premiums at a relatively low level. In some instances, a particularly high-risk activity may be excluded from the policy and, where a previously insured person has become such a high risk, the insurer may ultimately decline to offer insurance at all.

\section{(b) The problems of third-party liability insurance}

It has been observed that an insurer can apply a number of devices in first-party insurance to reduce the risk to which he is subject. Because the insurer has a wider variety of information available to him prior to granting insurance, he has a much greater control of the insured than is possible in the case of third-party insurance. In first-party insurance, the insurer is aware of the age, occupation and income of the insured, the amount of cover required and any special characteristics which might affect the risk. Because of this, the first-party insurer can segregate between low risks and high risks in a given insurance pool. The same cannot be said of the third-party insurer. The insurer has little or no control over the victim of professional negligence. Nor can it be said that the provider of a professional service is able to exercise any great degree of control. He will provide his service to both high-income and low-income earners alike, and a purported exclusion of liability may be struck out as void ${ }^{51}$ or unreasonable. ${ }^{52}$ In some instances, a disclaimer of liability will serve to negative the liability of a professional person to a non-contracting party. The disclaimer may serve to displace a duty of care which would otherwise be owed by showing that it is not reasonable for a person to rely on the advice of the professional. ${ }^{53}$ Where the provider of the service lacks control over the victim of professional negligence, narrow risk pools are not possible, and premiums have to be based upon expected average losses. Accordingly, premiums in third-party liability insurance are much higher than in the case of first-party insurance.

Where premiums are based on expected average loss, an adverse distributional effect may be produced by third-party insurance. In the case of negligence in the course of work related to conveyancing, ${ }^{54}$ the insurance premium will have to be based upon average losses. On the assumption that losses wil be greater in relation to higher priced properties, the purchaser of a lower priced property may subsidise the purchaser of a higher priced

\footnotetext{
${ }^{51}$ Unfair Contract Terms Act 1977 s 2(1) in relation to death or bodily injury.

52 Unfair Contract Terms Act 1977 s 2(2) in relation to harm other than death or bodily injury.

${ }^{53}$ See Hedley Byrne $v$ Heller [1964] AC 465; Harris $v$ Wyre Forest District Council [1988] 1 All ER 691. Cf Smith v Eric S Bush (a firm) [1987] 3 All ER 179 and see also Unfair Contract Terms Act 1977 s 13.

${ }^{54}$ Conveyancing gives rise to the greatest number of complaints resulting from the work of a solicitor. In September, $197628.5 \%$ of all claims arising out of the first 8 months of the Solicitors Master Indemnity Policy Scheme were in respect of conveyancing complaints: The Future of the Indemnity Insurance Scheme (Law Society, 1979) Table 2.
} 
property, since the cost of the solicitor's insurance premium will have been passed on to both. Likewise, where a low income earner is legally aided, it would seem to follow that the legal aid fund subsidises the high income earner to a certain extent.

A further difficulty of third party insurance is that the victim of professional negligence will recover the equivalent of what he would have obtained if he had sued to judgment. What is paid under a third-party liability policy may cover losses for which no first-party insured would seek cover. For example, a third-party insurer will pay in respect of nonpecuniary losses such as pain and suffering or the loss of a child's life, which are losses a first-party insured would rarely insure against. Furthermore, the beneficiary of a third-party policy is not subject to any excess provision in the policy, nor is the extent of cover restricted. As a result, the victim of medical negligence will seek the best medical care available to him. In contrast, a first-party insured will be restricted in the cover available to him according to the size of his premium. It follows from this that levels of recovery under thirdparty policies are considerably in excess of those under first-party policies.

Some of the techniques adopted in relation to first-party insurance to reduce the insurer's risk may also be adopted in third-party insurance. However, these techniques are applied against the insured, who may not be able to exercise any control over the potential victim of negligence, but they may be preferable to raising premiums. The insurer may increase excess provision in the policy so that the insured must pay in respect of losses up to a specified amount and he may lower the limits of coverage under the policy. These tactics have the effect of forcing high-risk members to contribute more to the harm they have caused. Such a person will have paid his premium and, because of the greater likelihood of his conduct causing harm, he will also bear the cost of contributing to the excess or seeking further insurance for any loss greater than that covered by the first policy. If these techniques do not have the effect of sufficiently reducing the risks of the insurer, a curious result may follow. If limits of coverage continue to fall and premiums rise, a point may be reached where what is provided is no longer insurance, because the event in respect of which the premium is paid is considered to be a virtual certainty.

An insurer might also choose to ask for proof of precautions taken by the insured to avoid the infliction of harm on a client or a third party. The danger, here, is that this could lead to defensive practices on the part of professional persons. The end result might be a proliferation of tests taken by doctors on patients, or excessive double-checking of advice given by solicitors, accountants and architects, which would increase the cost of the service provided. ${ }^{55}$

Further options available to an insurer might be to exclude certain high-risk activities from the policy, or to restrict claims to those filed during the policy term only. The effect of this last option would be to prevent a claim from being dealt with if it was filed in 1988 but related to negligence which occurred in 1987 . Such an approach would clearly be unacceptable to certain professions, particularly those concerned with buildings, where latent damage resulting from negligence does not reveal itself for a number of years. It would be necessary for the policy to operate on the basis of claims arising and, because of the nature

\footnotetext{
55 One effect of compulsory insurance upon Belgian architects appears to have been a requirement that a ground test should be conducted, even though this might not lessen the risk of loss. See Faure $\&$ Van den Bergh, Compulsory Insurance for Professional Liability (1989) Geneva Papers, p. 24.
} 
of the present limitation periods applicable to latent damage, an architect might need to keep his liability policy alive for several years after his retirement. ${ }^{56}$

\section{Advantages and disadvantages of compulsory third-party liability insurance}

\section{(i) Advantages}

A system of compulsory third-party liability can be said to have a number of advantages. ${ }^{57}$ It has the effect of ensuring that the victim is compensated. It also provides a remedy for the potential insolvency of the professional service provider, thereby avoiding an externality which would otherwise arise. Furthermore, liability insurance of this type has the effect of increasing social welfare by relieving those who are risk-averse from the insured risk of loss. Where third-party insurance is made compulsory, it has the effect of compelling a person to insure when he might not have been aware of the risks involved in his professional activities.

\section{(ii) Disadvantages}

The introduction of a system of compulsory third-party liability insurance also has a number of disadvantages which might be so great as to outweigh any advantages. These disadvantages relate to enforcement, cost, moral hazard and extent of coverage.

\section{(a) Enforcement}

A system of compulsory insurance would have to be properly enforced. Not providing an effective means of enforcement might result in an extensive failure on the part of professionals to take up insurance. ${ }^{58}$ These people are more likely than not to be those who are less well informed as to the extent of the risk of loss which may be created by a particular activity ${ }^{59}$ It has been observed that a compulsory insurance system would have to be enforced by a process of licensing or certification, such as that adopted in the U.K. in relation to motor vehicle insurance. ${ }^{60}$ Such a centralised process would create considerable costs, which might be disproportionate to the value of imposing a compulsory insurance requirement. ${ }^{61}$ It should be noted that motor vehicle insurance is, perhaps, not directly analogous to the insurance of professional risks, since there are many more drivers than there are pro-

56 It has been complained that an architect from whom work was commissioned when he was 60 might need to keep up his liability indemnity policy until the age of 102 or earlier death: The Financial Times, April 25th, 1985. But see now The Latent Damage Act 1986 which imposes a 15 year long stop on liability for latent defects in buildings. It follows that the architect's nightmares will now end at the age of 75 if he retires at 60 !

${ }^{57}$ See Faure \& Van den Bergh, op cit, section 2.1-2.4.

58 Consider the response of Belgian architects to a compulsory insurance system not backed by sanctions. Faure \& Van den Bergh op cit p. 25 point out that only $30-40 \%$ of architects are insured according to the architect's professional body and, according to insurers, cover extends to $60 \%$ of the profession. This still leaves $40 \%$ of architects uninsured.

${ }^{59}$ See Faure \& Van den Bergh op cit, section 2.4.

${ }^{60}$ The Royal Commission on Civil Liability and Compensation for Personal Injury (1978, Cmnd 7054 - I) para 321 (The Pearson Report).

61 Ibid. 
fessionals working within a given area. Professional persons are, without exception, members of a professional association, and it might be possible for a professional association to render third-party insurance compulsory by including the premium in the membership fee of the association. If a professional person is unable to practice without being a member of the association concerned, he would be compelled to contribute to the insurance fund without the need for Government intervention. Nevertheless, significant costs would be incurred by the professional body in setting up a system of certification, which would necessarily be passed on to the consumer by the professional providing the service.

\section{(b) Cost}

While it is true that a compulsory insurance system does take risk from those who are risk-averse, it should be enquired what cost might be involved in doing so. The cost of insurance cover might prove to be uneconomic in relation to small risks. Compelling a person to insure against small risks might involve taking out insurance in circumstances where such cover is no longer of utility. In the long term, such a stance would result in social loss, given that the consumer of the service would end up paying for protection which might reasonably be covered by a process of self-insurance on the part of the professional. In order to avoid the problems caused by small risks, an obvious solution is to allow excess provision in the policy, so that the professional self-insures in respect of a stated sum. ${ }^{62}$ However, in a compulsory insurance system, it could be the case that an excess provision in insurance policies is prohibited, in which case, the cover provided might not be of utility, since this would result in an over-payment by the consumer for the service provided.

A further compelling criticism of a compulsory insurance system is that it would lump together both low risks and high risks in one insurance pool. It has been observed that, in the case of non-compulsory insurance, if premiums rise excessively, low risk members of the pool may opt to self-insure. In a compulsory system, this option would not be possible, but the effect of compelling a professional to remain insured while insurance premiums rise might render it uneconomic to continue to provide the service.

One effect of combining high and low risks is that the insurer will be subject to potentially greater liability to indemnity. The insurer can adopt a number of alternative strategies to counteract this possibility, which will be considered in the context of the moral hazard. However, it remains the case that premiums will be calculated on the basis of expected average loss in third-party liability policies, and that the low risk insured will be required to subsidise the high risk members of the insurance pool. Because of the difficulties involved in determining the likelihood that an individual will cause a particular loss, there is a tendency on the part of insurers to calculate premiums on a collective basis, which would appear to result in increased premiums. It may be argued that allowing individual professionals to seek their own insurance cover might result in a reduction of the level of premiums. ${ }^{63}$

\section{(c) Moral Hazard}

It has been observed that one effect of a legal rule is to act as an incentive to loss prevention. However, the presence of compulsory third-party liability insurance may serve to

\footnotetext{
62 The Solicitors Master Policy Indemnity Scheme fixes the level of excess at $£ 500$ per partner.

63 Pettifer 80 Law Society Gazette 1196.
} 
reduce the incentive to take care if the insured knows that such loss as he may cause will be covered by his insurer. In the context of compulsory third-party liability insurance, the insurer will be faced with a combination of both low and high-risk members of his insurance pool. One response to this combination is that the insurer could raise premiums to cover the increased risk of having to provide an indemnity due to the presence of high-risk members of the insurance pool. However, raising premiums may cause some members of the pool to cease provision of services which might be regarded as beneficial to society. Alternatively, the insurer might seek to differentiate between low risks and high risks by other means. For example, he might choose to exclude certain high-risk activities from the cover provided ${ }^{64}$ or he might seek to differentiate between low and high risks by reference to past experience of claims. ${ }^{65}$ However, it would appear that because of the compulsory and institutional nature of such schemes, this may be impossible and that premiums will be similar for all insured persons. The Solicitors' Master Policy Indemnity Scheme does operate a premium loading system, ${ }^{66}$ but the deterrent value of this must be doubted since insurance cannot be refused however much claims on the insurance fund may exceed the premium paid. The reason for introducing the loading system is said to be to produce a fairer distribution of premiums rather than to act as a deterrent. ${ }^{67}$ Loading is based on the total amount paid to the insured rather than on the number of claims made by the insured. It follows that a firm of solicitors with an excellent record except for one disasterously large claim may be considerably worse off than a firm with a long record of fairly small claims. Because the excess provision in the policy is based on the number of partners, it may be the case that a sole practitioner with an excess of $£ 500$ will claim more from the insurers than a large partnership with a correspondingly higher excess provision. This represents a cross-subsidy of sole partners by other participants in the insurance pool. The same criticism would not apply as between practices with medium and large numbers of partners since the variable excess provision will be related to the turnover of the practice.

If the insurer is unable to differentiate between risks presented by individuals, premiums must be based on expected average loss and the result is that low risk members of the insurance pool subsidise the activities of high risk members.

\section{(d) Extent of cover}

A further problem which might be encountered in setting up a compulsory insurance scheme is to determine what limitations, if any, should be placed upon the amount of insurance cover available. ${ }^{68}$ It has been observed that any limit imposed would be arbitrary. ${ }^{69}$

\footnotetext{
${ }^{64}$ Experience of insurance of the risks created by solicitors shows that there has been an extension of the coverage. Lloyd's policies issued to solicitors used to define the indemnity as covering claims arising from any "neglect, omission or error". See Haseldine v Hosken [1933] 1 KB 822. Now, the Solicitors Master Policy Indemnity Scheme covers "any description of civil liability whatsoever incurred in connection with the Practice". The only pertinent exclusion concerns the fraudulent acts of the insured.

65 Professional ethics prevent the use of such information so as to discipline professionals with a bad claims record. The insistence on confidentiality is also provided for by Clause 4 of the Solicitors' Master Policy Indemnity Scheme.

66 Principals whose premium pool is exceeded by claims paid may have their premiums loaded on a sliding scale from $20 \%$ to $50 \%$.

${ }^{67}$ See Dugdale, The Quality of Professional Services II - Non-Litigious Controls (1983) 17 Law Teacher 171 at 172 .

68 The Pearson Report op cit para 322 and paras $1262-1265$

${ }^{69}$ Ibid para 1264.
} 
If the limit were to be set too low, gaps would appear in the insurance cover available and if the limit set were to be too high, premiums would rise to the prejudice of those persons presenting a low risk. Furthermore, if no limit were to be set, possible results might be higher prices to consumers and unreasonable financial burdens on professionals providing services. ${ }^{70}$

\section{The way ahead (or back?)}

It has been observed that there has been a steady expansion in the tortious liability of professional persons and that the existence of an insurance market may contribute to that expansion. Furthermore, the reaction of insurers in the face of such an expansion will be to raise premiums or adopt other defensive tactics which might render it uneconomic to provide certain services. To make third-party liability insurance compulsory might not be of any benefit, since there would appear to be no effective means of controlling the problem of moral hazard.

It has been noted that first-party loss insurance provides a better way of controlling the problem of moral hazard and it may be that some of the risks created in the course of professional activity may be better covered in this way. Other risks, particularly those arising out of medical malpractice, might be better covered by a compensation fund financed through taxation and levies on professionals. However, none of these moves would affect the potential for expansion in tortious liability.

It is suggested that it may be necessary to re-appraise what losses should be compensatable through the tort system. It has been observed that losses suffered as a result of professional negligence may include death, personal injury, emotional harm, damage to property, economic loss consequent to physical harm and pure economic loss. The first three involve a threat to personal integrity, whereas the remainder do not. It may be that personal integrity is worthy of greater protection than harm of an economic nature or damage to property and it can be argued from this point that tort law should not protect property rights at all. ${ }^{71}$ It should be appreciated that much of the property damage suffered as a result of professional negligence will be recoverable in a contractual action or may be protected by firstparty loss insurance.

It may be argued that there has been a recent trend in favour of protecting a person against violations of personal integrity resulting from professional negligence. In contrast, there would appear to be a retraction in the liability of a professional where the loss suffered relates to property or is purely financial loss.

In recent years, there has been a general tendency towards the expansion of liability for negligently inflicted emotional harm. It was once the case that damages could not be recovered where fear for one's safety was followed by emotional distress. ${ }^{72}$ However, a person was later able to recover where emotional harm was a direct consequence of a fear of

\footnotetext{
70 Ibid para 1262.

71 See Abel, Should Tort Law Protect Property Against Accidental Loss in The Law of Tort: Policies and Trends in Liability for Damage to Property and Economic Loss (Eds M Furmstrom \& H Beale) (Duckworth, 1985).

72 Victorian Railway Commissioners v Coultas (1888) 13 App Cas 222.
} 
harm to one's person..$^{73}$ Later still, actions for damages for nervous shock were entertained if there was a threat to the bodily safety of a close family member ${ }^{74}$ and where the plaintiff encountered the aftermath of an accident in which members of her family had been involved..$^{75}$ So also, it has now been recognised that a solicitor may be liable in damages for physical injuries and nervous shock suffered by a third party as a result of the solicitor's negligence. In Al-Kandari v Brown, ${ }^{76}$ the defendants' client, who was the plaintiff's husband, was required by a court order to deposit his passport with the defendants. The defendants negligently allowed the passport out of their hands with the result that the plaintiff's husband had access to it. The husband arranged for the plaintiff to be imprisoned in a van while he kidnapped the children of their marriage. The plaintiff was awarded $£$ 5,000 damages in respect of her physical injuries and her imprisonment and a further $£$ 15,000 was awarded in respect of the psychiatric harm suffered by the plaintiff as a result of losing her children. ${ }^{77}$ In contrast, if the harm suffered by a third party is purely financial, there may be a reluctance to allow the action to succeed. While it is the case that a third party who is the intended beneficiary of work carried out by a solicitor may be owed a duty of care, ${ }^{78}$ a third party who is not directly in the contemplation of a solicitor will be owed no such duty. ${ }^{79}$

The greater emphasis on personal integrity can also be found in the provisions of the Unfair Contract Terms Act 1977. If a professional person seeks to exclude or restrict liability for negligently causing death or bodily injury, the exclusion clause will be treated as having no effect ${ }^{80}$ However, an exclusion or disclaimer of liability is permitted in relation to negligently caused property damage, if it satisfies a requirement of reasonableness. ${ }^{81}$

One effect of a disclaimer of liability is to prevent the primary duty to exercise reasonable care from arising. ${ }^{82}$ However, where the primary duty concerns harm to the person as opposed to economic loss the disclaimer is less likely to be regarded as capable of displacing that duty. In Smith v Eric $S$ Bush (a firm) ${ }^{83}$ the defendants were employed by a building society to carry out a valuation on property which the plaintiff hoped to purchase. The

${ }^{73}$ Dulieu v White [1901] 2 KB 669.

${ }^{74}$ Hambrook v Stokes [1925] 1 KB 141.

${ }^{75}$ McLoughlin v O'Brian [1983] AC 410.

${ }^{76}$ [1988] 1 All ER 833.

${ }^{77}$ It is important that the shock was suffered as a result of a threat to the personal integrity of the plaintiff and her children. There would be less reason to compensate a person for nervous shock suffered as a result of property damage. But cf Attia v British Gas Plc [1987] 3 All ER 455 where, as a preliminary point of law, it was held that damages can be recovered for nervous shock suffered as a result of witnessing the destruction of one's home where the damage is caused by the defendant's negligence. It should be noted that there is still ample opportunity to deny the plaintiff success on the grounds of reasonable foreseeability or causation.

${ }^{78}$ Ross v Caunters [1980] Ch 297; Gartside v Sheffield, Young \& Ellis [1983] 1 NZLR 37.

${ }^{79}$ Clarke v Bruce Lance (a firm) [1988] 1 All ER 364.

${ }^{80}$ Unfair Contract Terms Act 1977 s 2(1).

81 Unfair Contract Terms Act 1977 s 2(2).

${ }^{82}$ Hedley Byrne v Heller [1964] AC 465.

${ }^{83}$ [1987] 3 All ER 179. 
defendants negligently failed to check that the chimneys of the house were adequately supported when it was noted that two chimney breasts in upstairs rooms had been removed. The surveyors reported that the house was readily saleable for owner occupation and that no essential repairs were required. However, the house was a dangerous structure which was unfit for habitation. The defendants sought to rely on a disclaimer which stated that the valuation was confidential and intended for the use of the building society alone and that no responsibility for the accuracy of the valuation was accepted. It was held that the disclaimer was meaningless if it did not apply to the defendants' responsibility in negligence. Accordingly, the disclaimer could be struck out on the ground that it did not satisfy the requirement of reasonableness. While, the harm suffered by the plaintiff was damage to property, the dangerous state of the house could have caused serious personal injury had the plaintiff been in the bedroom at the time the chimneys collapsed.

If the harm suffered by the plaintiff is pure economic loss and there is no likelihood of personal injury, a similar disclaimer may be considered to fashion the nature of the duty undertaken by the defendant. In Harris $v$ Wyre Forest District Council ${ }^{84}$ a valuation undertaken by the defendants stated that the house was worth the asking price. Subsequently, it was discovered that the house was subject to settlement with the result that it was virtually unsaleable. The plaintiff had relied on the advice given by the defendant, but a disclaimer stated that the defendants accepted no responsibility for the accuracy of their valuation. The Court of Appeal held that the disclaimer prevented a duty of care from coming into existence and that a notice of the type issued by the defendants is not one which the Unfair Contract Terms Act bites.

In relation to building services, it also appears to be the case that personal integrity is placed above property damage and economic loss. The decisions of the House of Lords in Anns $v$ Merton London Borough Council ${ }^{85}$ and Junior Books $v$ Veitchi ${ }^{86}$ appeared to have opened up the potential for an expanding liability for negligently caused economic loss arising in the context of the provision of building services. However, it has been stressed that statutory powers conferred on local authorities to inspect building work are intended to protect the health and safety interests of occupiers. ${ }^{87}$ In order to protect the occupier against a danger to his health or safety, damages may be awarded to put right the defects in the building on the basis that prevention is better than cure. In contrast, the purpose of these statutory powers is not to safeguard building developers against economic losses. ${ }^{88}$ The ability of a plaintiff to recover economic losses in an action for negligence has been put in further doubt by the decision of the House of Lords in D \& F Estates Ltd. v Church Commissioners for England ${ }^{89}$ in which it was held that a builder owes no duty of care to a subsequent occupier of a house in respect of defects in the property which result in its diminution

84 [1988] 1 All ER 691.

85 [1978] AC 728.

86 [1983] AC 520.

${ }^{87}$ Peabody Donation Fund (Governors) v Sir Lindsay Parkinson \& Co Ltd [1985] AC 210 at 241 per Lord Keith.

88 Ibid. See also Investors in Industry Commercial Properties Ltd v South Bedfordshire District Council [1986] 1 All ER 787.

${ }^{89}$ [1988] 2 All ER 992. 
in value. Lord Bridge's judgment seems to suggest that such losses are not recoverable in a negligence action, even where they present an imminent danger to the health or safety of the occupant. However, Lord Oliver, in a concurring judgment, considered that an imminent danger to health or safety could be averted by means of an award of damages so as to allow the danger to be removed. ${ }^{90}$ It is suggested that the latter view is preferable in that it recognises the importance of protecting a person's interest in his personal integrity.

\section{Conclusion}

It has been observed that the tortious liability of the professional person has expanded in recent years, not only in terms of what conduct gives rise to liability, but also in terms of what types of loss are compensatable. This expansion may be augmented by the presence of insurance. It is undoubtedly the case that the practice of insurance has provided an atmosphere in which the expansion of liability can take place. It may be argued that this expansion in liability could lead to an insurance crisis. However, expanding negligence liability may not be the only contributing cause of a possible insurance crisis. For example, it may be said that increased claims consciousness on the part of plaintiffs is, in part, to blame.

In order to meet the financial consequences of expanding liability, insurers may raise premiums or adopt other tactics so as to reduce the risk that they bear. Again, the expansion of negligence liability may not be the only cause of rising insurance premiums. For example, a fall in interest rates will result in a decrease in the insurer's return on his investments, which in turn, may cause premiums to rise. Furthermore the market for insurance may drop if there is an increase in the number of businesses prepared to set up mutual insurance schemes. The resultant narrowing of the insurer's risk pool may cause premiums to rise.

In the case of third-party liability insurance, it is quite possible that the insurer's liability to indemnify will be so great that it may be difficult to keep premiums within acceptable levels. To make such insurance compulsory would avoid the possibility that some professionals might choose to self-insure, but little, it seems, can be done to avoid the problem of moral hazard.

It is suggested that a move away from third party insurance might be a possibility, and that property interests might be better protected by first party loss insurance or an action for damages for breach of contract. By contrast, personal integrity is more worthy of protection, and harm such as death, personal injury and psychic harm might be better dealt with by means of a compensation fund financed out of taxes and levies upon professional persons.

${ }^{90}$ Ibid at 1014. 